\title{
COMBINING ABILITY FOR YIELD AND YIELD ATTRIBUTES IN RICE (Oryza sativa L.) GENOTYPES USING CMS SYSTEM
}

\author{
C. L. Sharma, N. K. Singh, A. K. Mall ${ }^{*}$ K. Kumar and O. N. Singh ${ }^{1}$ \\ Department of Genetics and Plant Breeding, ND University of Agriculture \& Technology \\ Kumarganjg, Faizabad-224 229 (Uttar Pradesh), India
}

\begin{abstract}
Seventy five hybrids generated from crossing three cytoplasmic male sterile lines with 25 testers were studied along with parents for combining ability and gene action involved in expression of characters in rice. The GCA and SCA effects were significant for all the characters except seedling height, indicating the importance of both additive and non additive genetic components. The ratio of gca and sca variance was less than unity for all the characters also indicated preponderance of non additive genetic variance and suggested good prospects of the exploitation of variation through hybrid breeding. Amongst the parental lines, UPR-2080-24-1-R, IR-60076-1-R, PNR-165-10-6-R and IR-58025A were found to be good general combiners which can be taken up to generate desirable segregates for further selection. None of the crosses showed significant sca effects for all the characters. On the basis of per se performance and high sca effects, IR-58025-A x CSRC-50-2-1-4-BR, PMS-10-A x IR-42688-2-118-6-3, RPMS-100-A x UPRI-92-79-R and NMS-4-A x IR-32419-28-3-1-3-R were good specific combiners for grain yield plant ${ }^{-1}$ and their components which could be used for exploitation of heterosis for yield.
\end{abstract}

Key words: CMS line, Line $x$ tester analysis, combining ability, gene action, rice

\section{INTRODUCTION}

Rice (Oryza sativa L.) is the staple food for 65 percent of the global population and forms the cheapest source of food, energy and protein. But it is an unfortunate paradox that yield of rice, the staple food of Southeast Asia, is lowest in the area

\footnotetext{
* Corresponding author: Project Coordinating Unit (Forage Crops), Indian Grassland \& Fodder Research Institute, Gwalior Road, Jhansi-284 003 (Uttar Pradesh), India. Email: ashutoshkumarmall@gmail.com

${ }^{1}$ Crop Improvement Division, Central Rice Research Institute, Cuttack-753 006 (Orissa), India
}

Received: 13.08.2012 
where the crop has been cultured extensively since ancient times and the plant exists in its greatest varietal diversity (Khush, 1997). To meet the food demand of the growing population and to achieve food security in the country, the present production levels need to be increased by 2 million tones every year, which is possible through heterosis breeding and other innovative breeding approaches (Pandey et al., 2010). To increase production and productivity in irrigated ecosystem, innovative breeding approaches are needed. Development of rice hybrids with yield advantage of 30 percent over the existing hybrids is the turning point for increasing production and productivity (Yuan, 1994). Further improvement in parental lines will give a steady increase in hybrid yield (Ikehashi et al., 1994). However, varieties good in per se performance may not necessarily produce desirable progenies when used in hybridization. Knowledge about combining ability is, therefore, important in selecting suitable parents for hybridization, proper understanding of underlying inheritance of quantitative traits and also in identifying the promising crosses for further use in breeding programme. In view of above, the present investigation was under taken with the objective of studying the combining ability of rice genotypes for yield and yield attributes.

\section{MATERIALS AND METHODS}

The three cytoplasmic male sterility lines viz., IR-58025-A, PMS-10-A and NMS-4-A possessing 'wild abortive (WA)' type of cytoplasm, were crossed with 25 genetically diverse pollen parents viz., IR-32419-28-3-1-3-R, IR-64-R, IR-47310-944-3-1-R, IR-29723-140-3-2-1-R, IR-54771-29-2-1-R, IR-52256-9-2-2-1-R, IR59915-140-3-3-3-R, IR-42688-2-118-6-3-R, IR-70-R, IR-60076-1-R, IR-10376-49-11-R, PNR-10-6-R, JR-82-1-10-R, HUR-3021-R, BTC-E 509-96-1-R, UPR-2080-241-R, CSR-21-R, CSRC-50-2-1-4-BR, RP-2932-2528-R, CSR-50-2-1-1-4-BR, CSR32-B-B-1-BR, R-971-2505-2-1-R, AS-9-19106-R, RP-3441-MRST-43-1917-R and UPRI-92-97-R in line $x$ tester $\left(\mathrm{L} \mathrm{x} \mathrm{T}\right.$ ) fashion. A total of $75 \mathrm{~F}_{1} \mathrm{~s}$ were produced during wet season 2008. The resulted $75 \mathrm{~F}_{1}$ s, their 28 parents (25+3) and standard checks i.e. Narendra Shanker Dhan-2 were evaluated in Randomized Block Design with three replications at the Genetics and Plant Breeding Farm of Narendra Deva University of Agriculture and Technology, Kumarganj (Faizabad), India during wet season 2009. Thirty days old single seedling hill ${ }^{-1}$ was planted at a spacing of $20 \times 15 \mathrm{~cm}$ with three meter length row having three rows in each entry. The experiment was conducted with normal package of practices with need based plant protection measures. Observations were recorded on five competitive plants of the middle row of each plot for 12 quantitative characters. Observations were recorded on seedling length $(\mathrm{cm})$, number of leaves plant ${ }^{-1}$, days to $50 \%$ flowering, plant height $(\mathrm{cm})$, number of effective tillers plant ${ }^{-1}$, spikelets plant ${ }^{-1}$, filled grains panicle ${ }^{-1}$, spikelet fertility (\%), 1000-grain weight (g), biological yield plant ${ }^{-1}(\mathrm{~g})$, harvest index and grain yield plant ${ }^{-1}(\mathrm{~g})$. Standard statistical procedures were followed for analysis of variance of combining ability (Kempthorne, 1957). 


\section{RESULTS AND DISCUSSION}

Analysis of variance for different characters revealed that the mean squares due to males, females and males $\mathrm{x}$ females were highly significant for all the characters (Table 1). This indicated that the treatments had wide genetic diversity among themselves. The significant $\mathrm{F}$ value of male $\mathrm{x}$ females showed the importance of specific combining ability effects for the expression of those characters in the crosses. These results emphasized the importance of combining ability studied and indicated good prospects for selection of suitable parents and crosses for the development of appropriate varieties and hybrids. The partitioning of combining ability variance into fixable and non fixable variances indicated both additive and non additive gene action playing a significant role in controlling the expression of all the characters. The ratio of GCA and SCA variance was less than unity for all the characters also indicated preponderance of non additive genetic variance and suggested good prospects of the exploitation of variation for yield and yield attributes through hybrid breeding. Similar results were reported by Kumar et al., 2007; Pradhan and Singh, 2008, Salgotra et al., 2009.

All the parents with significant negative general combining ability (gca) estimates for days to $50 \%$ flowering and plant height while, significant positive gca effects for the remaining characters are considered as good general combiner. The estimate of gca effects (Table 2) showed that the 14 male parents were found to be good general combiner for grain yield plant ${ }^{-1}$ and UPR-2080-24-1-R was the best combiner among them that possessed significant desirable gca effects for most of the traits viz., early plant vigour (seed length and number of leaves plant ${ }^{-1}$ ), number of effective tillers plant ${ }^{-1}$, spikelets plant $^{-1}$ and biological yield plant ${ }^{-1}$. The parent IR60076-1-R and PNR-165-10-6-R were good general combiners among males that possessed high GCA effects for seedling length, number of effective tillers plant ${ }^{-1}$, grains panicle ${ }^{-1}$, spikelet fertility, 1000-grain weight, harvest index, biological and grain yield plant ${ }^{-1}$ with desirable gca effects for plant height and earliness. As late and tall varieties are preferred to low land ecosystem, the genotype UPR-2080-24-1$\mathrm{R}$ was found suitable for the same and expressed significant and desirable GCA effects for almost all the characters. Among the female parents, IR-58025-A was the best general combiner for biological and grain yield plant ${ }^{-1}$ along with high GCA effects for seedling length, number of leaves plant ${ }^{-1}$, days to $50 \%$ flowering, spikelets plant $^{-1}$, spikelet fertility, 1000-grain weight and harvest index. Rest of the female parents were poor general combiner for grain yield plant ${ }^{-1}$ and most of the characters interestingly were those parents identified as short statured and early maturing. It may be suggested that in a multiple crossing programme involving UPR-2080-24-1R, IR-60076-1-R and PNR-165-10-6-R as parents may to taken up to generate desirable segregates for selection.

The performance of parents per se was an indication of their GCA effects for all the above traits (Kumar et al., 2007). The behavior of parents was good indication 
of the performance of their hybrids as reported by Sanghera and Hussain (2012). Thus, per se performance itself may be regarded as criteria for selecting parents.

Out of 75 crosses, 34 were identified as specific good combinations for grain yield plant ${ }^{-1}$ (Table 3 ). The promising specific combinations for grain yield along with other traits were IR-58025-A x CSRC-50-2-1-4-BR, NMS-4-A x IR-32419-283-1-3-R, PMS-10-A x IR-42688-2-118-6-3-R, and PMS-10-A x UPRI-92-79-R. It was observed that majority of the crosses with SCA effects for grain yield were involved with high/low combinations indicating additive $\mathrm{x}$ dominance type of gene interactions for expression of traits. But very few crosses showing low/low general combiners showed high sca effects, suggesting the epistatic gene action which may be due to genetic diversity in the form of heterozygous loci. Also, very few crosses having high/high general combiners showed high SCA effects, which could be ascribed to predominance of additive $\mathrm{x}$ additive type of gene action. Thus, in majority of the crosses, high SCA effects for grain yield were attributed to dominance and epistatic gene action and in only few cases attributed to additive interactions, which was also reported by Pradhan et al. (2006) and Pradhan and Singh (2008).

Desirable SCA effects for days to $50 \%$ flowering were IR-58025-A x AS19106-R, PMS-10-A x RP-3441-MRST-43-1917-R and PMS-10-A x CSRC-50-2-14-B-R. For plant height, negative estimates of SCA were desirable and promising specific combiners were IR-58025-A x CSR-32-B-B-1-B-R and IR-58025-A x CSRC-50-2-1-4-B-R. The cross combinations PMS-10-A x UPRI-92-79-R, PMS-10A x IR-10376-49-1-1-R and NMS-4-A x IR-32419-28-3-1-R were good combiners for number of effective tillers plant ${ }^{-1}$. The promising specific combiners for spikelets plant $^{-1}$ were IR-58025-A x RP-3441-MRST-43-1917-R, IR-58025-A x IR-60076-1-R and PMS-10-A x IR-52256-9-2-2-1-R. The cross combinations IR-58025-A x CSRC50-2-1-4-B-R, NMS-4-A x IR-32419-28-3-1-R and PMS-10-A x AS-19106-R were showed the highest SCA effects for spikelets fertility. For grains panicle ${ }^{-1}$, the cross IR-58025-A x IR-70-R, IR-58025-A x IR-60076-1-R and PMS-10-A x IR-52256-92-2-1-R exhibited high specific combining ability effects for the trait. Good specific combiners for 1000 grain weight were PMS-10-A x UPRI-92-79-R, NMS-4-A x IR47310-94-4-3-1-R and NMS-4-A x IR-59915-140-3-3-3-R while, IR-58025-A x RP3441-MRST-43-1917-R, NMS-4-A x IR-54771-29-2-3-R and PMS-10-A x IR42688-2-118-6-3-R for harvest index. The genotypes PMS-10-A/AS-19106-R, NMS4-A/IR-32419-28-3-1, PMS-10-A/IR-10376-49-1-1-R, PMS-10-A/UPRI-92-79-R and IR-58025-A/IR-42688-2-118-6-3-R showed high SCA effects for biological yield plant ${ }^{-1}$. Present study revealed that the crosses IR-58025-A/RP-3441-MRST-431917-R, IR-58025-A/CSRC-50-2-1-4-B-R, NMS-4-A/IR-32419-28-3-1-R and PMS10-A/UPR-192-79-R produced superior and potential hybrids for grain yield ${ }^{-1}$.

The parents involved in these hybrids were either high $\mathrm{x}$ high or high $\mathrm{x}$ low with regard to GCA effects. In case of H x H GCA crosses, there are possibilities of complementary epistatic effect acting in the direction of additive effects of the good 
combiners and can be utilized through single plant selections. The crosses of $\mathrm{H} \times \mathrm{L}$ GCA group with the expression of positive SCA effects may be due to the dominant $x$ recessive interaction, expected to produce desirable segregates and may be improved through population improvement. In case of L x L crosses, with high SCA, non-additive type of variation can be exploited by multiple crosses followed by inter matting among desirable segregates.

\section{CONCLUSION}

The acceptable amount of per se performance and SCA effects for yield and other yield contributing traits indicates that hybrids can be commercially exploited in present conditions after screening of F's at different locations and for various seasons. However, the IR-58025-A x CSRC-50-2-1-4-BR, PMS-10-A x IR-42688-2-118-6-3, RPMS-100-A x UPRI-92-79-R and NMS-4-A x IR-32419-28-3-1-3-R crosses were good specific combiners with the high performance and high SCA effects for developing high yielding hybrid rice varieties.

\section{REFERENCES}

Ikehashi, H., Zou, J.S., Moon, H.P., and Maruyana, K. 1994. Wide compatibility genes and Indica-Japonica heterosis in rice for temperate countries. In Virmani, S.S. (ed.) Hybrid Rice Technology: New Development and Future Prospects, pp. 1-6. Int. Rice Res. Inst., Manila, The Philippines.

Kempthorne, O. 1957. An introduction to genetic statistics. John Wiley and Sons, Inc., London.

Khush, G.S. 1997. Origin, dispersal, cultivation and variation of rice. Plant Molecular Biology, 35: 25-34.

Kumar, S., Singh, H.B., and Sharma, J.K. 2007. Combining ability analysis for grain yield and other associated traits in rice. Oryza, 44 (2): 108-114.

Pandey, M.P., Verulkar, S.B., and Sharma, D. 2010. Rice research: past achievement, present scenario and future trust. Indian Journal of Agricultural Sciences, 80 (6): 447-469.

Pradhan, S.K., and Singh, S. 2008. Combining ability and gene action analysis for morphological and quality traits in basmati rice. Oryza, 45 (3): 193-197.

Pradhan, S.K., Bose, L.K., and Meher, J. 2006. Studies on gene action and combining ability analysis in basmati rice. Journal of Central European Agriculture, 7 (2): 267-272.

Salgotra, R.K., Gupta, B.B., and Singh, P. 2009. Combining ability studies for yield and yield components in basmati rice. Oryza, 46 (1): 12-16.

Sanghera, G.S., and Hussain, W. 2012. Heterosis in relation to combining ability per se performance in temperate rice (Oryza sativa L.). Pakistan Journal of Agriculture Research, 25 (3): 186-195.

Yuan, L. P. 1994. Increasing yield potential in rice by exploitation of heterosis. In: Virmani, S.S. (ed) Hybrid Rice Technology: New Development and Future Prospects, pp. 1-6. Int. Rice Res. Inst., Manila, The Philippines. 
Table 1: Analysis of variance for combining ability for twelve characters in rice

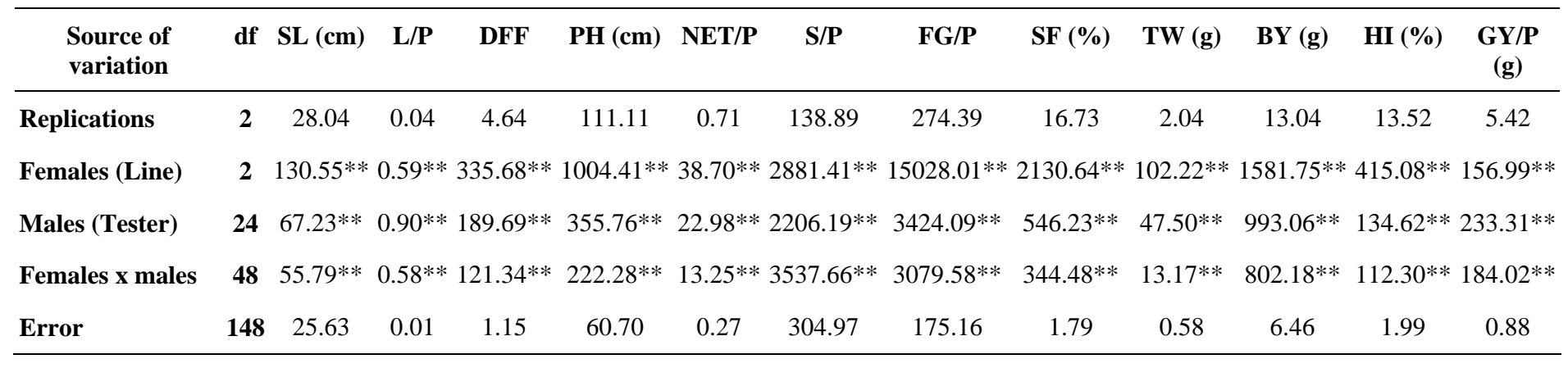

** Significant at $1 \%$ level of probability

Legends: SL: Seedling Length (cm); L/P: Number of leaves plant ${ }^{-1}$; DFF: Days to 50 per cent flowering; PH (cm); NET/P: Number of effective tillers plant ${ }^{-1}$, S/P: Spikelets plant ${ }^{-1}$; FG/P: Filled grains panicle ${ }^{-1}$; SF (\%): Spikelet fertility; TW (g): 1000 grain weight; BY/P: Biological yield plant ${ }^{-1}$; HI (\%): Harvest Index and GY/P: Grain yield plant ${ }^{-1}$ 
Table 2: Estimates of general combining ability (gca) effects of parents for twelve characters in rice

\begin{tabular}{|c|c|c|c|c|c|c|c|c|c|c|c|c|}
\hline Parents Characters & SL (cm) & $\mathbf{L} / \mathbf{P}$ & DFF & PH (cm) & NET/P & $\mathrm{S} / \mathbf{P}$ & FG/P & SF (\%) & TW (g) & BY (g) & HI (\%) & GY/P (g) \\
\hline \multicolumn{13}{|l|}{ Male Parents } \\
\hline IR-32419-28-3-1-3-R & 0.76 & $0.11^{* *}$ & $-1.15^{* *}$ & $-5.36^{* *}$ & $1.16^{* *}$ & $6.44-$ & $-36.69 * *$ & $-21.79 * *$ & $-3.88 * *$ & $-7.25^{* *}$ & $-5.94 * *$ & $-5.13^{* *}$ \\
\hline IR-46-R & -3.07 & $-0.26 * *$ & $-1.07 * *$ & $-7.93 * *$ & $-1.54^{* *}$ & $17.80^{* *}$ & -1.91 & $5.51^{* *}$ & $0.90 * *$ & $-5.65 * *$ & $2.98 * *$ & $-0.67 * *$ \\
\hline IR-47310-94-4-3-1-R & -1.26 & 0.05 & $-1.87^{* *}$ & $-12.04 * *$ & $-1.94 * *$ & 12.75 & $-9.21^{*}$ & $2.62 * *$ & $-1.00^{* *}$ & $2.84^{* *}$ & $2.35^{* *}$ & $1.71^{* *}$ \\
\hline IR-29723-140-3-2-1-R & -0.07 & 0.02 & $-4.03 * *$ & $-10.34 * *$ & $-0.48^{* *}$ & $-30.22 *$ & -12.02 & $4.32 * *$ & $2.74 * *$ & $4.04 * *$ & $-1.33^{* *}$ & -0.03 \\
\hline IR-5477129-2-3-R & -2.88 & $-0.40 * *$ & $-0.78^{* *}$ & -4.53 & $-0.36 * *$ & $-13.02 * *$ & $-17.67 * *$ & $-5.55^{* *}$ & $1.34 * *$ & $-12.61 * *$ & $-5.25^{* *}$ & $7.67 * *$ \\
\hline IR-52256-9-2-2-1-R & 1.30 & $0.19 * *$ & $0.96 * *$ & -4.26 & $-2.87 * *$ & $37.58^{* *}$ & $30.71 * *$ & -0.30 & $0.91 * *$ & $9.47 * *$ & $4.57^{* *}$ & $-1.38 * *$ \\
\hline IR-59915-140-3-3-3-R & 0.84 & $0.39 * *$ & -0.69 & $-7.99 * *$ & $-1.86^{* *}$ & -7.53 & 0.90 & 0.85 & $1.02 * *$ & $-3.30 * *$ & 0.46 & $-1.63 * *$ \\
\hline IR-42688-2-118-6-3-R & $-3.42 *$ & 0.04 & $2.15^{* *}$ & $-7.39 * *$ & $-4.96 * *$ & 1.81 & -1.64 & $-6.18 * *$ & $1.83 * *$ & $-3.75 * *$ & $1.34^{* *}$ & $1.90^{* *}$ \\
\hline IR-70-R & 2.28 & $0.50^{* *}$ & $2.58 * *$ & $-5.18 * *$ & $-1.12^{* *}$ & 3.03 & $-8.96 *$ & $-9.10 * *$ & $2.55 * *$ & $-2.93 * *$ & $-1.79 * *$ & $-1.69 * *$ \\
\hline IR-600-76-1-R & $4.46^{*}$ & $-0.41^{* *}$ & $-2.24 * *$ & 1.10 & $0.73^{* *}$ & 3.00 & $11.95^{* *}$ & $2.19 * *$ & $2.15^{* *}$ & $9.47^{* *}$ & $2.22^{* *}$ & $5.04 * *$ \\
\hline IR-10376-49-1-1-R & -3.06 & $-0.28 * *$ & $-1.58^{* *}$ & $-7.54 * *$ & $-0.42 *$ & -8.44 & 1.36 & $3.61^{* *}$ & $1.49 * *$ & $11.08 * *$ & $3.85^{* *}$ & $5.88 * *$ \\
\hline PNR-165-10-6-R & 0.35 & $0.32 * *$ & $-1.24 * *$ & 2.12 & $1.24^{* *}$ & 6.46 & $17.34^{* *}$ & $5.34^{* *}$ & $-1.98 * *$ & $6.68 * *$ & $3.23^{* *}$ & $4.31^{* *}$ \\
\hline JR-82-1-10-R & 0.45 & 0.03 & $0.93 *$ & -0.48 & $2.27^{* *}$ & -6.14 & 5.00 & $4.40^{* *}$ & $0.77^{* *}$ & $4.52^{* *}$ & $4.95^{* *}$ & $4.84^{* *}$ \\
\hline HUR-3021-R & -0.90 & $-0.13^{* *}$ & $2.81^{* *}$ & -0.14 & $-0.72 * *$ & 7.48 & $21.42 * *$ & $6.70^{* *}$ & $3.62 * *$ & $11.20 * *$ & $3.15^{* *}$ & $6.14 * *$ \\
\hline BTC-E 509-96-R & 0.79 & $0.15^{* *}$ & $10.44 * *$ & 0.81 & $1.25^{* *}$ & 0.53 & $10.33^{*}$ & $12.84^{* *}$ & $2.01 * *$ & $16.59 * *$ & $1.11^{*}$ & $6.78 * *$ \\
\hline UPR-2080-24-1-R & 2.88 & $0.54^{* *}$ & $9.35^{* *}$ & 9.63 & $1.65^{* *}$ & $19.47^{* *}$ & $32.54 * *$ & $7.43^{* *}$ & $1.79 * *$ & $20.44 * *$ & 0.82 & $7.80 * *$ \\
\hline CSR-21-R & 2.62 & $0.19 * *$ & $4.06^{* *}$ & 1.38 & $-1.22^{* *}$ & 6.2 & $9.75 *$ & $1.30^{* *}$ & $1.26^{* *}$ & $3.46 * *$ & $3.85^{* *}$ & $2.97 * *$ \\
\hline CSRC-50-2-1-4-B-R & 1.69 & $0.17^{* *}$ & -0.66 & $5.98^{*}$ & -0.20 & $15.10^{*}$ & -9.08 & $12.29^{* *}$ & 0.10 & $-7.00 * *$ & $-1.94 * *$ & $-3.44 * *$ \\
\hline RP-2932-2528-R & 3.06 & $0.58^{* *}$ & $7.39 * *$ & 1.16 & $-0.63^{* *}$ & $15.40^{* *}$ & $26.29 * *$ & $6.05^{* *}$ & $0.93^{* *}$ & $15.78^{* *}$ & $-4.58 * *$ & $2.47 * *$ \\
\hline CSR-50-2-1-1-4-B-R & $5.99 * *$ & $-0.31^{* *}$ & $-2.93 * *$ & -1.94 & $0.68^{* *}$ & $-13.35 *$ & $26.45^{* *}$ & $-9.87 * *$ & $-0.73^{* *}$ & $-17.34^{* *}$ & 0.53 & $-7.08 * *$ \\
\hline CSR-32-B-B-1-B-R & -0.46 & $-0.18^{* *}$ & $-3.01 * *$ & $6.02 *$ & -0.18 & $-18.88^{* *}$ & 0.19 & $8.77^{* *}$ & $-3.78 * *$ & $6.30 * *$ & -0.14 & $1.44^{* *}$ \\
\hline IR-971-2505-2-1-R & -0.26 & $-0.15^{* *}$ & $-8.70 * *$ & $8.61 * *$ & -0.05 & $-22.53 * *$ & $-26.83 * *$ & -0.24 & $-1.96 * *$ & $-14.56^{* *}$ & $-5.56 * *$ & $-8.49 * *$ \\
\hline AS-19106-R & -0.78 & $-0.31 * *$ & $-8.69 * *$ & $9.83 * *$ & $-0.58^{* *}$ & $-19.66 * *$ & $-39.73 * *$ & $-8.48 * *$ & $-4.44^{* *}$ & $-11.42 * *$ & $-8.08 * *$ & $-9.82 * *$ \\
\hline
\end{tabular}




\begin{tabular}{|c|c|c|c|c|c|c|c|c|c|c|c|c|}
\hline Parents Characters & SL (cm) & $\mathbf{L} / \mathbf{P}$ & DFF & PH (cm) & NET/P & $\mathbf{S} / \mathbf{P}$ & FG/P & SF (\%) & TW (g) & BY (g) & HI (\%) & GY/P (g) \\
\hline RP-3441-MRST-43-1917-R & -3.31 & $-0.34 * *$ & $-3.43 * *$ & 3.83 & $-0.54 * *$ & $14.34^{*}$ & $10.32 *$ & -0.67 & $-2.86 * *$ & $-11.87 * *$ & $-5.43 * *$ & $-5.28 * *$ \\
\hline UPRI-92-79-R & $-4.94 * *$ & $-0.52 * *$ & $1.77^{* *}$ & -0.80 & $0.77 * *$ & 7.88 & $12.09 * *$ & $2.52 * *$ & $-2.87 * *$ & $-5.28 * *$ & $4.65 * *$ & $1.05^{*}$ \\
\hline SE $\left(\mathrm{S}_{\mathrm{gi}}\right)$ males & 1.69 & 0.03 & 0.36 & 2.60 & 0.17 & 5.82 & 4.41 & 0.45 & 0.25 & 0.85 & 0.47 & 0.31 \\
\hline SE (Sgi-Sgi) & 2.39 & 0.05 & 0.50 & 3.67 & 0.24 & 8.23 & 6.24 & 0.63 & 0.36 & 1.20 & 0.67 & 0.44 \\
\hline \multicolumn{13}{|l|}{ Female parents } \\
\hline IR-58025-A & $1.15^{*}$ & $0.08^{* *}$ & $2.24 * *$ & -0.87 & $-0.30 * *$ & $7.11^{* *}$ & $15.98^{* *}$ & $5.97^{* *}$ & $0.84^{* *}$ & $2.73^{* *}$ & $1.16^{* *}$ & $1.60^{* *}$ \\
\hline PMS-10-A & $-1.44 *$ & 0.01 & $-1.96^{* *}$ & $4.02 * *$ & $-0.52 * *$ & -2.88 & $-5.00 * *$ & $-1.70^{* *}$ & $0.50^{* *}$ & $2.57 * *$ & $-2.71 * *$ & $-0.37 * *$ \\
\hline NMS-4-A & 0.29 & $-0.09 * *$ & $-0.28^{*}$ & $-3.14^{* *}$ & $0.82 * *$ & $-4.24 *$ & $-10.98 * *$ & $-4.27 * *$ & $-1.33^{* *}$ & $-5.30 * *$ & $1.55^{* *}$ & $-1.228^{* *}$ \\
\hline SE $\left(S_{g i}\right)$ Females & 0.58 & 0.01 & 0.12 & 0.90 & 0.06 & 2.02 & 1.53 & 0.15 & 0.09 & 0.29 & 0.16 & 0.11 \\
\hline SE (Sgi-Sgi) & 0.83 & 0.02 & 0.17 & 1.27 & 0.08 & 2.85 & 2.16 & 0.22 & 0.12 & 0.42 & 0.23 & 0.15 \\
\hline
\end{tabular}

*, ** Significant at $5 \%$ and $1 \%$ probability levels, respectively.

Legends: SL: Seedling Length (cm); L/P: Number of leaves plant ${ }^{-1}$; DFF: Days to 50 per cent flowering; PH (cm); NET /P: Number of effective tillers plant $^{-1}$, S/P: Spikelets plant ${ }^{-1}$; FG/P: Filled grains panicle ${ }^{-1}$; SF (\%): Spikelet fertility; TW (g): 1000-grain weight; BY/P: Biological yield plant ${ }^{1}$; HI (\%): Harvest Index and GY/P: Grain yield plant ${ }^{-1}$

*In case of spikelet fertility, test weight and grain yield plant ${ }^{-1}$ corresponding maintainer lines data were taken due to CMS lines are unable to produce it. 
Table 3: Estimates of specific combining ability (sca) effects for grain yield and their component characters in rice

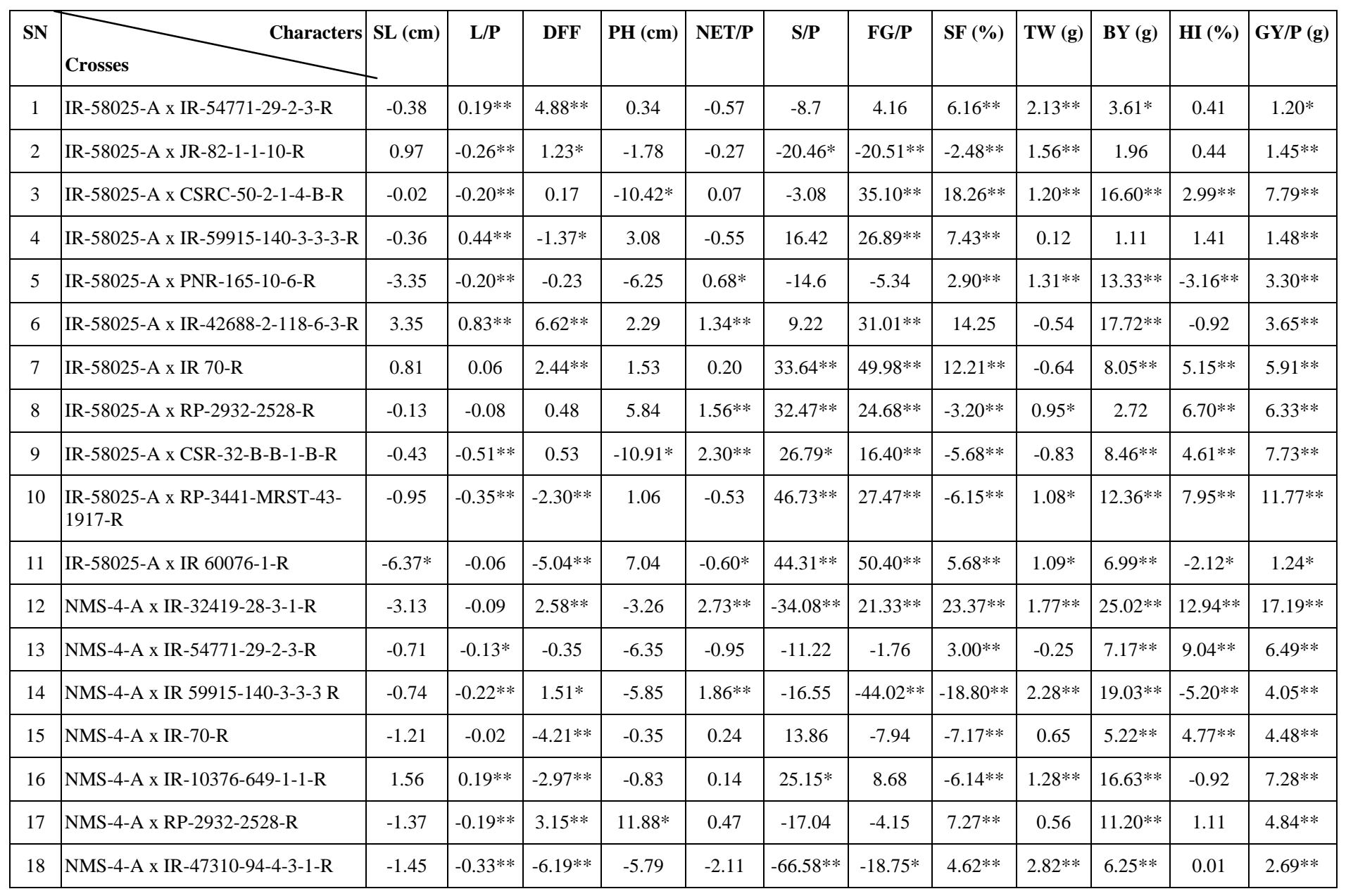




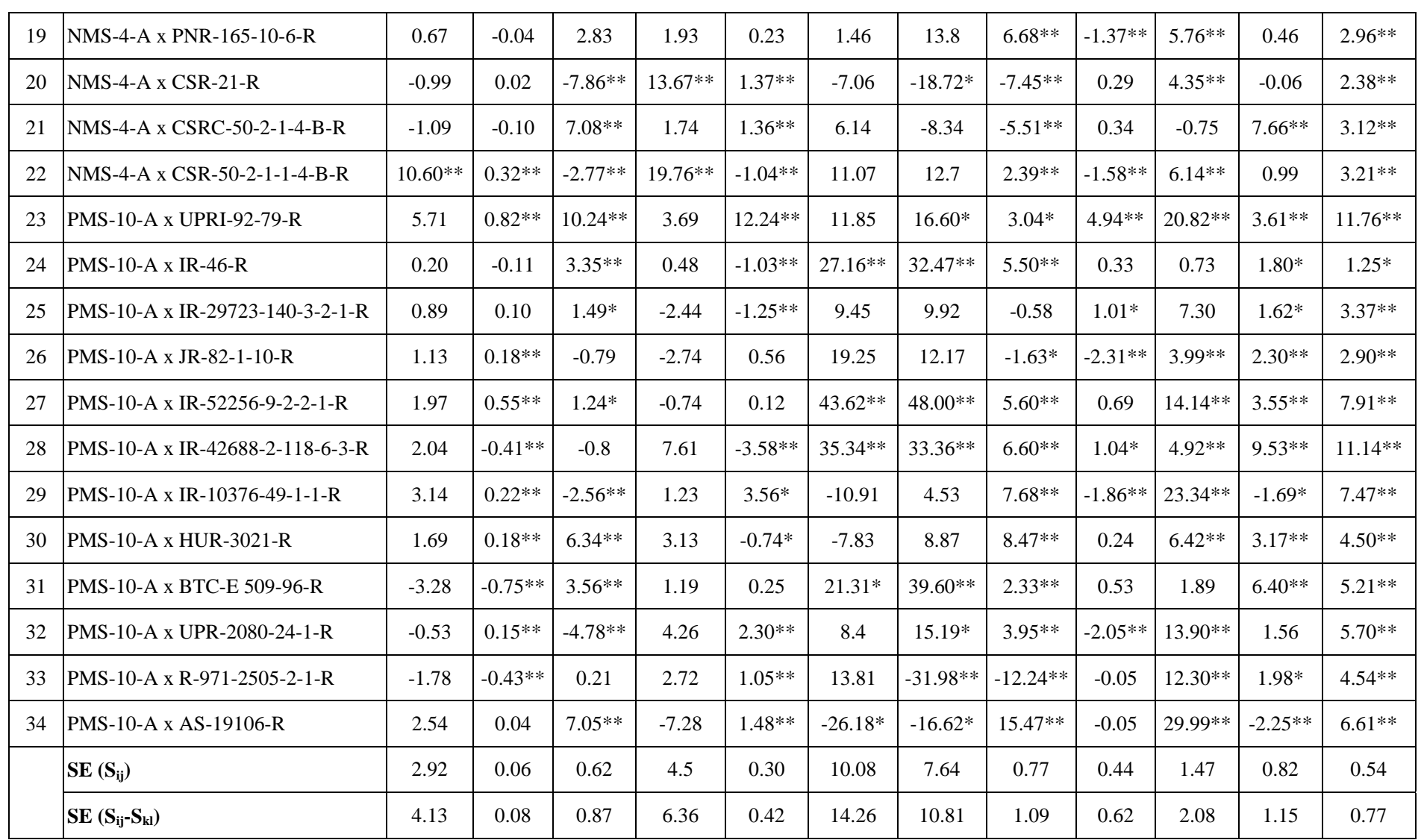

*, ** Significant at $5 \%$ and $1 \%$ probability levels, respectively.

Legends: SL: Seedling Length (cm); L/P: Number of leaves plant ${ }^{-1}$; DFF: Days to 50 per cent flowering; PH (cm); NET /P: Number of effective tillers plant ${ }^{-1}$, S/P: Spikelets plant ${ }^{-1}$; FG/P: Filled grains panicle ${ }^{-1}$; SF (\%): Spikelet fertility; TW (g): 1000 grain weight; BY/P: Biological yield plant ${ }^{-1}$; HI (\%): Harvest Index and GY/P: Grain yield plant 
Table 4: Prospective cross combinations based on sca effects for seed yield and suggested breeding strategy

\begin{tabular}{|c|c|c|c|c|}
\hline Cross combinations & $\begin{array}{l}\text { SCA } \\
\text { effects }\end{array}$ & $\begin{array}{c}\text { GCA effects } \\
\text { of combining } \\
\text { parents }\end{array}$ & $\begin{array}{l}\text { Other characters with } \\
\text { significant SCA effects }\end{array}$ & \\
\hline \multicolumn{5}{|l|}{ For early maturing } \\
\hline IR-58025-A x IR 60076-1-R & $1.24^{* *}$ & $\mathrm{H} \times \mathrm{L}$ & $\begin{array}{l}\mathrm{S} / \mathrm{P}, \quad \mathrm{FG} / \mathrm{P}, \quad \mathrm{SF}, \quad \mathrm{TW} \quad \& \\
\mathrm{BY} / \mathrm{P}\end{array}$ & $\begin{array}{l}\text { Heterosis Breeding/Mass } \\
\text { selection with concurrent } \\
\text { random mating }\end{array}$ \\
\hline $\begin{array}{l}\text { IR-58025-A } \quad x \quad \text { RP-2932- } \\
2528-R\end{array}$ & $6.33^{* *}$ & $\mathrm{H} \times \mathrm{H}$ & $\begin{array}{l}\text { NET/P, S/P, FG/P, TW \& } \\
\text { HI }\end{array}$ & $\begin{array}{l}\text { Heterosis } \\
\text { Breeding/Conventional } \\
\text { Breeding Methods }\end{array}$ \\
\hline $\begin{array}{l}\text { IR-58025-A x CSR-32-B-B- } \\
\text { 1-B-R }\end{array}$ & $7.73 * *$ & $\mathrm{H} \times \mathrm{L}$ & $\begin{array}{l}\text { NET/P, S/P, FG/P, BY/P \& } \\
\text { HI }\end{array}$ & $\begin{array}{l}\text { Heterosis Breeding/Mass } \\
\text { selection with concurrent } \\
\text { random mating }\end{array}$ \\
\hline $\begin{array}{l}\text { IR-58025-A X RP-3441- } \\
\text { MRST-43-1917-R }\end{array}$ & $11.77^{* *}$ & $\mathrm{H} \times \mathrm{L}$ & $\begin{array}{l}\text { S/P, } \\
\text { HI }\end{array}$ & \multirow{4}{*}{\begin{tabular}{ll} 
Heterosis & \multicolumn{2}{c}{ Breeding/Mass } \\
selection with concurrent \\
random mating
\end{tabular}} \\
\hline \begin{tabular}{|l} 
PMS-10-A $\quad x \quad$ IR-42688-2- \\
118-6-3-R
\end{tabular} & $11.14^{* *}$ & $\mathrm{~L} \times \mathrm{H}$ & $\begin{array}{l}\text { S/P, FG/P, SF, TW, BY/P } \\
\& \text { HI }\end{array}$ & \\
\hline $\begin{array}{l}\text { PMS-10-A x UPR-2080-24- } \\
1-\mathrm{R}\end{array}$ & $5.70^{* *}$ & $\mathrm{~L} \times \mathrm{H}$ & $\begin{array}{l}\mathrm{L} / \mathrm{P}, \mathrm{NET} / \mathrm{P}, \mathrm{FG} / \mathrm{P}, \mathrm{SF} \& \\
\mathrm{BY}\end{array}$ & \\
\hline $\begin{array}{l}\text { NMS-4-A x CSR-50-2-1-1- } \\
4-B-R\end{array}$ & $3.21^{* *}$ & $\mathrm{~L} \times \mathrm{L}$ & $\mathrm{SL}, \mathrm{L} / \mathrm{P}, \mathrm{PH}, \mathrm{SF} \& \mathrm{BY} / \mathrm{P}$ & \\
\hline \multicolumn{5}{|l|}{ For Late Maturing } \\
\hline IR-58025-A x IR-70-R & $5.91^{* *}$ & $\mathrm{H} \times \mathrm{L}$ & S/P, FG/P, SF, HI \& BY/P & \multirow{5}{*}{$\begin{array}{l}\text { Heterosis Breeding/Mass } \\
\text { selection with concurrent } \\
\text { random mating }\end{array}$} \\
\hline $\begin{array}{l}\text { PMS-10-A x BTC-E-509- } \\
\text { 96-R }\end{array}$ & $5.21^{* *}$ & $\mathrm{~L} \times \mathrm{H}$ & $\begin{array}{l}\text { NET/P, FG/P, S/F, TW, } \\
\text { BY \& HI }\end{array}$ & \\
\hline PMS-10-A x UPRI-92-79-R & $11.76^{* *}$ & $\mathrm{~L} \times \mathrm{H}$ & $\begin{array}{l}\text { L/P, NET/P, FG/P, SF, } \\
\text { TW, BY/P \& HI }\end{array}$ & \\
\hline $\begin{array}{l}\text { PMS-10-A x IR-52256-9-2- } \\
\text { 2-1-R }\end{array}$ & $7.91 * *$ & $\mathrm{~L} \times \mathrm{H}$ & $\begin{array}{l}\mathrm{L} / \mathrm{P}, \mathrm{S} / \mathrm{P}, \mathrm{FG} / \mathrm{P}, \mathrm{SF}, \mathrm{BY} / \mathrm{P} \\
\& \mathrm{HI}\end{array}$ & \\
\hline $\begin{array}{l}\text { NMS-4-A x IR-32419-28-3- } \\
1-\mathrm{R}\end{array}$ & $17.19^{* *}$ & $\mathrm{~L} \times \mathrm{L}$ & S/P, FG/P, SF \& HI & \\
\hline
\end{tabular}

** Significant at $1 \%$ level of probability

Legends: SL: Seedling Length $(\mathrm{cm})$; L/P: Number of leaves plant ${ }^{-1}$; DFF: Days to 50 per cent flowering; PH (cm); NET /P: Number of effective tillers plant $^{-1}$, S/P: Spikelets plant ${ }^{-1}$; FG/P: Filled grains panicle ${ }^{-1}$; SF (\%): Spikelet fertility; TW (g): 1000 grain weight; BY/P: Biological yield plant ${ }^{-1}$; HI (\%): Harvest Index and GY/P: Grain yield plant ${ }^{-1}$ 